\title{
PENGARUH PENAMBAHAN UBI JALAR UNGU TERHADAP DAYA TERIMA MI BASAH
}

\author{
Fara Merisna ${ }^{1}$, Ichsan Affan ${ }^{2}$, Andriani MS ${ }^{3}$ \\ 1,2,3 Jurusan Gizi, Politeknik Kesehatan Kemenkes Aceh, JL. Soekarno Hatta, Kampus Terpadu Poltekkes \\ Kemekes Aceh RI Aceh Lampeneurut, Aceh Besar. Telp.065146126, e-mail:merisna_f@gmail.com
}

\begin{abstract}
ABSTRAK
Pemanfaatan ubi jalar ungu di Indonesia masih terbatas pada beberapa jenis produk pangan saja ini pun dalam jumlah kecil. Ubi jalar ungu (Ipomoea batatas L. var. Ayamurasaki), memiliki warna kulit dan umbi berwarna ungu kehitaman (ungu pekat). Dalam penelitian ini, ubi jalar ungu ditambahkan dalam tepung terigu, Aplikasi ubi jalar ungu dalam pembuatan mi dapat memperkaya komposisi zat gizi pada mi basah dan juga menambah fenomena warna mi menjadi warna yang menarik karena dagingnya yang berwarna ungu. Penelitian bertujuan untuk mengetahui pengaruh penambahan ubi jalar ungu terhadap daya terima warna, aroma, rasa, dan tekstur mi basah. Rancangan penelitian bersifat eksperimental untuk melihat pengaruh penambahan ubi jalar ungu terhadap daya terima mi basah, dengan Rancangan Acak Lengkap (RAL) Non Faktorial, tiga perlakuan dan tiga kali pengulangan $(3 x 3=9)$ unit percobaan. Penelitian ini dilaksanakan pada tanggal 20 Agustus 2013 di Laboratorium Teknologi Pangan Jurusan Gizi Poltekkes Kementerian Kesehatan Aceh. Hasil penelitian bahwa perlakuan yang ada pengaruh nyata terhadap warna mi basah ubi jalar ungu ( $F$ hitung 187,64 > F tabel 3,23). Ada pengaruh nyata terhadap aroma mi basah ubi jalar ungu $(F$ hitung 165,46 > F tabel 3,23). Ada pengaruh nyata terhadap rasa mi basah ubi jalar ungu (F hitung 26,61 > F tabel 3,23). Ada pengaruh nyata terhadap tekstur mi basah ubi jalar ungu (F hitung 12,39 > F tabel 3,23). Kesimpulan, yaitu hasil uji organoleptik menunjukkan bahwa rata-rata tertinggi daya terima warna, aroma, rasa, dan tekstur terletak pada perlakuan B (penambahan ubi jalar ungu $75 \mathrm{~g}$ ). Penelitian ini dapat dilanjutkan untuk daya simpan mi basah dengan penambahan ubi jalar ungu dan pengaruh lama perebusan mi basah dengan penambahan ubi jalar ungu tehadap daya terima warna.
\end{abstract}

Kata Kunci : Mi Basah, Penambahan Ubi Jalar Ungu, Daya Terima.

\begin{abstract}
Utilization of purple sweet potato in Indonesia is still limited to only a few types of food products is also in small quantities. Purple sweet potato (Ipomoea batatas L. var. Ayamurasaki), has a tuber skin color and purple-black (dark purple). In this study, added in a purple sweet potato flour, sweet potato purple applications in the manufacture of noodles can enrich the nutrient composition on a wet noodle and also add color phenomenon noodles into attractive colors for purple colored flesh. The study aims to determine the effect of purple sweet potato on the acceptability of color, aroma, flavor, and texture of wet noodles. The study design is experimental to see the effect of adding a purple sweet potato to power thanks wet noodles, with a completely randomized design $(C R D)$ non factorial, three treatments and three repetitions $(3 \times 3=9)$ experimental units. This study was conducted on August 20, 2013 at the Laboratory of Food Technology. The research concludes that treatments exist significant effect on the color of wet noodles purple sweet potato (187.64 F count> F table 3,23). No significant effect on the scent of wet noodles purple sweet potato (165.46 F count> F table 3,23). No significant effect on the taste of wet noodles purple sweet potato (26.61 F count $>$ F table 3,23). No significant effect on the texture of wet noodles purple sweet potato (12.39 F count> F table 3,23). In conclusion, ie organoleptic test results showed that the highest average received power of color, aroma, flavor, and texture lies in the treatment $B$ (addition of purple sweet potato $75 \mathrm{~g}$ ). This research can be continued for the storability of wet noodles with the addition of purple sweet potato and influence long wet noodles boiling with the addition of purple sweet potato color tehadap received power.
\end{abstract}

Keywords : $\quad$ Noodle, addition of Purple Sweet Potatoes, Southwestern Receive. 